УДК 656.212 .5

Д-р техн. наук О.М. Огар,

Ю.В. Куртяк, Ю.С. Лунякіна, Д.В. Півень

\title{
РОЗРОБЛЕННЯ УЗАГАЛЬНЕНОЇ ПРОЦЕДУРИ РОЗРАХУНКУ РАЦІОНАЛЬНИХ КОНСТРУКТИВНО-ТЕХНОЛОГІЧНИХ ПАРАМЕТРІВ СОРТУВАЛЬНИХ ГІРОК
}

Вступ. Ефективність експлуатації сортувальних гірок суттєво залежить від якості їх конструкції та управління процесами у сортувальному комплексі й технології сортувального процесу, що застосовується. Основними напрямками підвищення вказаної ефективності перш за все $\epsilon$ впровадження ресурсозберігаючих технологій і конструкцій.

Актуальність. Для визначення раціональних конструктивно-технологічних параметрів сортувальних гірок використовуються різні підходи, які в основному базуються на процедурі розрахунку спочатку конструктивних параметрів, а вже потім для отриманої за обраним критерієм раціональної конструкції - технологічних параметрів. Повною мірою такі підходи комплексними назвати не можна. Крім того, більш достовірні результати розрахунків можна отримати тільки шляхом імітаційного моделювання сортувального процесу, а програмні модулі, що існують на даний момент, обмежені у здатності вирішення вказаного завдання.

Аналіз досліджень і публікацій. Серед останніх праць в галузі розрахунку конструктивних параметрів сортувальних гірок найбільш відомими $€$ праці
М.В. Правдіна і С.А. Бессоненка [1-5]. Запропонований ними комплексний розрахунок параметрів сортувальних гірок базується на використанні імовірнісних показників. Як критерій оптимізації обрано мінімум тривалості розформування составів. Розраховані за даним критерієм параметри не завжди можуть сприяти збереженню паливно-енергетичних i виробничих ресурсів.

Над створенням та удосконаленням імітаційних моделей сортувального процесу працювали такі вчені, як Бобровський B.I., Іванченко В.M., Лебединська О.М., Муратов А.А., Муха Ю.А., Шабельников О.М., Шепілова О.Г. та ін. [610]. Недоліком запропонованих моделей $є$ можливість розрахунку лише технологічних параметрів сортувальних гірок - швидкості розпуску составів, швидкості виходу відчепів 3 гальмових позицій спускної частини і підгіркових колій та ін.

Формулювання мети (постановка завдання). Метою даних досліджень $\epsilon$ розроблення наукового підходу до розрахунку раціональних конструктивнотехнологічних параметрів сортувальних гірок шляхом моделювання сортувального процесу. 
Формування узагальненої процедури розрахунку раціональних конструктивно-технологічних сортувальних гірок. Визначення раціональних конструктивно-технологічних параметрів системи „Сортувальна гірка” базується на моделюванні процесів насуву, розпуску i розформування составів. У зв'язку з цим виникає завдання створення адекватної імітаційної моделі сортувального процесу на гірках, що проектуються або експлуатуються.

Оскільки система „Сортувальна гірка” $\epsilon$ динамічною системою 3 безперервним часом, сортувальний процес повинен описуватися диференціальними рівняннями, в яких незалежною змінною $\epsilon$ час. Вказані рівняння дозволять отримати параметри станів системи у моменти $t_{0}, t_{1}$, $\ldots, t_{i}$. На кожному кроці моделювання $\Delta t$ необхідно одночасно розглядати рух состава, що насувається, і скочування відчепів 3 гірки, для чого в імітаційні моделі, як правило, вводиться системний час.

Крім того, імітаційна модель повинна передбачати можливість застосування будь-якого режиму регулювання швидкості скочування відчепів, а для забезпечення високої точності розрахунків сил, що діють на відчеп у процесі насуву, розпуску та скочування 3 гірки, слід використовувати його осьову модель.

Узагальнену процедуру визначення раціональних конструктивно-технологічних параметрів сортувальних гірок наведено на рисунку.

Вихідними даними до визначення вказаних параметрів $€$ (блок 2):

1) розрахунковий період $m_{p}, \mathrm{p}$;

2) середньодобові розміри переробки;

3) характеристика структури вагонопотоку, що надходить у переробку;

4) середня температура зовнішнього повітря, вибіркові середні та середньоквадратичні відхилення швидкості і напрямку вітру у випадково обрану добу кожного місяця розрахункового періоду;

5) координати характерних точок плану елементів сортувального комплекту (парку приймання, сортувальної гірки та підгіркового парку);

6) координати точок перелому поздовжнього профілю;

7) параметри кривих дільниць колій, стрілочних переводів і глухих перехрещень;

8) характеристики регулювання швидкості скочування відчепів та їх вартості;

9) додаткові дані для розрахунку експлуатаційних витрат.

Після введення вихідних даних для випадково обраної доби кожного місяця розрахункового періоду формуються залежності швидкості і напрямку вітру від часу та моделюється призначення, тип, число осей, вага й основний питомий опір кожного вагона, а також заповнення підгіркових колій перед розпуском першого состава (блок 3 ).

Функціонування сортувальної гірки розглядається при різних варіантах швидкості розпуску составів $V_{p_{z}}$, для чого задається відповідний цикл (блок 4). Число цих варіантів $N$ визначається діапазоном можливих швидкостей розпуску (при ручному розчепленні вагонів від 0,8 до $1,9 \mathrm{~m} / \mathrm{c}$, автоматичному - від 0,8 до $2,2 \mathrm{~m} / \mathrm{c}$ ) і величиною дискретного кроку $\Delta V_{p}$.

Після ідентифікації швидкості розпуску у відповідності до номера іiі варіанта розраховуються середні тривалості заїзду гіркового локомотива у парк приймання, насуву i розпуску состава, осаджування вагонів на підгіркових коліях та рівень завантаження гірки при наявності одного гіркового локомотива (блок 5). Якщо рівень завантаження гірки перевищує 0,85 (блок 6), приймається два гіркових локомотиви (блок 7), інакше - один (блок 8). 


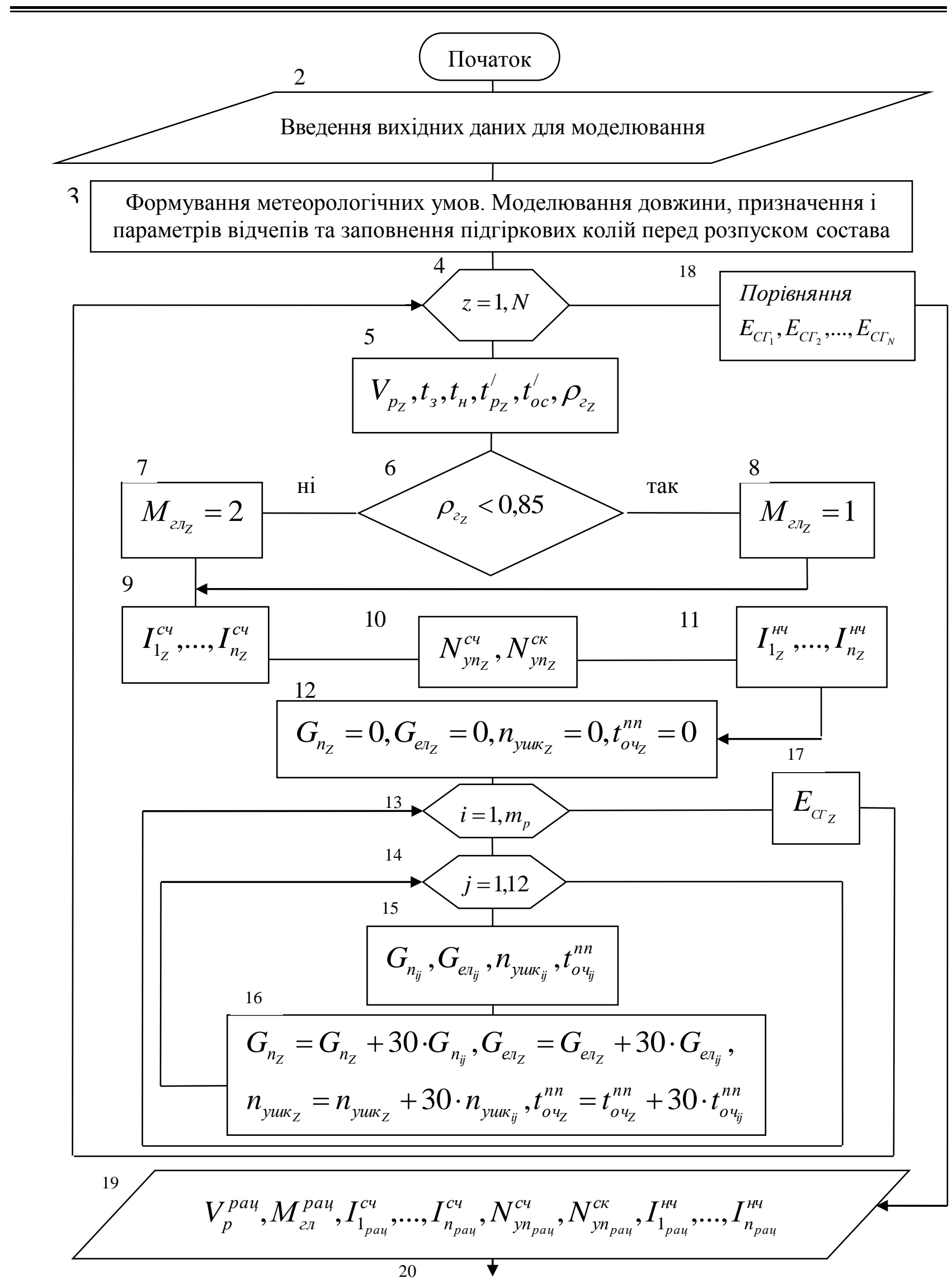

Рис. Узагальнена процедура визначення раціональних конструктивно-технологічних параметрів сортувальних гірок 
Далі визначаються раціональні параметри поздовжнього профілю спускної (блок 9) і насувної (блок 11) частин гірки та розрахунок потрібного числа вагонних уповільнювачів (блок 10), базуючись на результатах розрахунку потужності гальмових засобів.

На наступному етапі розраховуються та додаються витрати палива гірковими локомотивами на насув і розпуск составів, витрати електроенергії на регулювання швидкості скочування відчепів, число пошкоджених вагонів і додатковий простій составів у парку приймання в очікуванні розформування, який $є$ функцією гіркових технологічних інтервалів у вихідному варіанті і варіанті, що розглядається (блоки 15, 16). Реалізується дана процедура шляхом прирівнювання вказаних параметрів до нуля (блок 12) та задавання циклів для числа розрахункових років (блок 13) і числа місяців (блок 14).

\begin{abstract}
Після цього для кожного варіанта швидкості розпуску составів розраховується економічний ефект від упровадження конструкції, технічного оснащення і технології роботи сортувальної гірки (блок 17).

Шляхом порівняння результатів розрахунку економічних ефектів визначаються i виводяться на друк раціональні конструктивно-технологічні параметри сортувальної гірки, а саме: швидкість розпуску составів, число гіркових локомотивів, крутизна елементів поздовжнього профілю та число вагонних уповільнювачів (блоки 18, 19).

Висновки.

Впровадження раціональних конструктивно-технологічних параметрів сортувальних гірок, що розраховані 3 використанням запропонованої процедури, дасть змогу отримати приріст синергетичного ефекту за період життєвого циклу.
\end{abstract}

\section{Список літератури}

1. Правдин, Н.В. Расчет параметров сортировочной горки с учетом случайных ходовых свойств отцепов [Текст] / Н.В. Правдин, С.А. Бессоненко // Трансп.: наука, техн., упр. - 2007. - № 7. - С. 8-15.

2. Правдин, Н.В. Определение уклонов скоростных участков и тормозных позиций на спускной части сортировочной горки [Текст] / Н.В. Правдин, С.А. Бессоненко // Трансп.: наука, техн., упр. - 2008. - № 9. - С. 6-10.

3. Бессоненко, С.А. Оптимизация параметров сортировочной горки по времени расформирования составов [Текст] / С.А. Бессоненко // Трансп.: наука, техн., упр. - 2007. № 9. - С. 30-34.

4. Бессоненко, С.А. Комплексный расчет уклонов продольного профиля спускной части и высоты сортировочной горки по вероятностным показателям [Текст] / С.А. Бессоненко // Трансп.: наука, техн., упр. - 2006. - № 7. - С. 12-19.

5. Бессоненко, С.А. Оптимизация основных параметров сортировочной горки [Текст] / С.А. Бессоненко // Совершенствование эксплуатационной работы железных дорог: сб. науч. ст. / ред. С.А. Бессоненко, А.В. Дмитренко. - Новосибирск, 2008. - С. 4-25.

6. Муха, Ю.А. Имитационное моделирование процесса скатывания отцепов при выполнении горочных расчетов [Текст] / Ю.А. Муха, А.А. Муратов // Механизация и автоматизация сортировочного процесса на станциях: межвуз. сб. науч. тр. Днепропетровск, 1990. - С. 11-20.

7. Иванченко, В.Н. Новый подход к управлению процессом роспуска составов на сортировочной горке [Текст] / В.Н. Иванченко, Н.Н. Лябах, А.А. Сепетый // Труды РИИЖТа. Ростов н/Д, 1984. - С. 34-41. 
8. Шабельников, А.Н. Системы автоматизированных сортировочных горок на базе промышленных компьютеров [Текст] / А.Н. Шабельников // Автоматика, связь, информатика. - 2001. - № 11. - С. 13-16.

9. Лебединская, Е.Н. Математическая модель программы роспуска составов с сортировочной горки [Текст] / Е.Н. Лебединская, Е.Г. Шепилова // Междунар. сб. науч. трудов. - Ростов н/Д, 1998. - С. 31-37.

10. Бобровский, В.И. Представление продольного профиля сортировочных горок в АСУ расформированием составов [Текст] / В.И. Бобровский // Информационноуправляющие системы на железнодорожном транспорте. - 1996. - № 1, 2. - С. 19-25.

Ключові слова: сортувальна гірка, конструктивно-технологічні параметри, імітаційна модель.

\section{Анотаціï}

Проаналізовано наукові підходи до визначення раціональних конструктивнотехнологічних параметрів сортувальних гірок. Сформовано процедуру розрахунку вказаних параметрів.

Проанализированы научные подходы к определению рациональных конструктивнотехнологических параметров сортировочных горок. Сформирована процедура расчета указанных параметров.

Scientific approaches to the definition of sorting humps rational design and technological parameters are analyzed. Procedure of calculation of the indicated parameters is formed. 